\title{
Effects of water stress on the growth status of five species of shrubs
}

\author{
Pingwei Xiang ${ }^{1, a}$, Xiaoli Ma ${ }^{1, b}$, Xuefeng Liu ${ }^{1, c}$, Xiangcheng Yuan ${ }^{1, d}$, \\ Zhihua $\mathrm{Fu}^{2, \mathrm{e}^{*}}$ \\ ${ }^{1}$ Chongqing three gorges academy of agricultural sciences, Wanzhou, Chongqing, China \\ ${ }^{2}$ Chongqing Three Gorges Vocational College, Wanzhou, Chongqing,China \\ a1294983629@qq.com,b545298645@qq.com,c1152753665@qq.com, \\ d307593107@qq.com, e2436270441@qq.com
}

*Corresponding author. Pingwei Xiang and Xiaoli Ma contributed equally to this work.

\begin{abstract}
Keywords: Water stress; shrubs; leaf relative water content; leaf water retention
Abstract: A pot experiments were conducted to study the effects of water stress on plant Blade retention, leaf relative moisture content (LRWC), Morphology and growth status, five drought-resistant plants (Pyracantha angustifolia, Pyracantha fortuneana, Pyracantha fortuneana 'Harlequin', Ligustrum japonicum 'Howardii', Photinia glabra $\times$ Photinia serrulata ) were used as materials. The results showed that the drought resistant ability of five species of shrubs from strong to weak as follows: Ligustrum japonicum 'Howardii', Pyracantha fortuneana, Pyracantha angustifolia, Photinia glabra $\times$ Photinia serrulata, Pyracantha fortuneana 'Harlequin'. It was found with several Comprehensive indicators that the drought tolerance of Ligustrum japonicum 'Howardii' was significantly higher than that of the other four species, and its adaptability to water deficit was stronger, Therefore, according to the drought resistance ability of tree species, it is suggested that planting Ligustrum japonicum 'Howardii' and Pyracantha fortuneana, in areas with severe water shortage can effectively maintain soil and water and improve the ecological environment.
\end{abstract}

\section{Introduction}

Drought is one of the main limiting factors of vegetation growth and recovery [1], as a major survival problem we are facing now and will face for a long time, people have attached great importance to it [1-2].Water has a significant impact on the process of plant growth [3]. When plants are stressed by water, they can adapt to the adverse environment through appropriate morphological changes to reduce or avoid system damage [4-6]. Therefore, it is of great theoretical and practical significance to study the growth status of plants under drought conditions for the improvement of water-saving cultivation techniques, the desertification control and the restoration of ecological environment in China [7]. A pot experiments were conducted to study the effects of water stress on plant blade retention, leaf relative moisture content (LRWC), Morphology and growth status, five drought-resistant plants were used as materials, in order to provide references for the selection of drought-tolerant tree species and further research.

\section{Materials and Methods}

Materials Collection. Two drought-resistant plants (Pyracantha fortuneana and Pyracantha angustifolia) were collected from the farmland of Ya'an Campus of Sichuan Agricultural University in June, 2011. Three drought-resistant plants (Pyracantha fortuneana 'Harlequin', Ligustrum japonicum 'Howardii'and Photinia glabra×P.fraseri) were collected from zhejiang senhe seed industry co., LTD., pixian county, sichuan province.

Experimental Design. In this experiment, potted water control method was adopted, and rhizosphere water stress was the main stress in drought stress treatment.Since September 1, 2012, dry and early stress has been divided into the degree of water stress by the relative water content of soil. The relative water content of soil in the control group (CK) is $85 \%+5 \%$ of the field water 
holding capacity (FC). The relative water content of soil under mild stress (T1) was $65 \%$ plus or minus $5 \%$ FC. The relative water content of soil under moderate stress (T2) was $45 \%+$ $5 \%$ FC.Severe stress (T3) : $25 \%$ plus or minus 5\%FC.Each treatment was 6 plants and repeated 3 times. Using the SC II type intelligent soil rapid moisture tester is in every day 16:00-18:00 soil relative water content.Drought stress after 2 months, i.e. on November 1, the hybrid sampling method, from 8:00 to 10:00 in the morning in the material of the same parts of every branch (from the top down 1/3) in functional leaf samples determination of enzymatic protection system related indicators. The determination of the relative water deficit (RWD), adopt the method of east China normal university of biology, plant physiology and. The determination of water retention, using the methods of huang yan mei. The relative water deficit and water retention of leaves should be measured[8-9].The ground diameter and plant height were measured on September 1, 2012 (the initial stage of treatment) and November 1, 2012 (the end stage of treatment). Comprehensive evaluation was conducted in accordance with the standards according to the observation records of growth performance [10].

Statistical Analyses. Statistical analyses were conducted using statistical software of SPSS 18.0. Data were analyzed by one-way ANOVA with least significant difference at $5 \%$ confidence level , and chart was maked using Microsoft Excel2010.

\section{Results and Discussion}

Effects of water stress on leaf water retention of five kinds of shrubs. As shown in Fig. 1, with the increase of water stress, five kinds of plants are presented the phenomenon that leaf water retention increasing. The leaf water retention of Ligustrum japonicum 'Howardii' and firethorn class (Pyracantha fortuneana, Pyracantha angustifolia and Pyracantha fortuneana 'Harlequin') increased with the increase of drought degree. And the capacity of Photinia glabra $\times$ Photinia serrulata's CK is higher than firethorn class but lower than Ligustrum japonicum 'Howardii', T1's water retention increased, and then it doesn't change as the drought increases. While the leaf water retention about Ligustrum japonicum 'Howardii' in the processing were higher than other four kinds of plants, thus, Ligustrum japonicum 'Howardii' has the highest drought resistance in several plants.

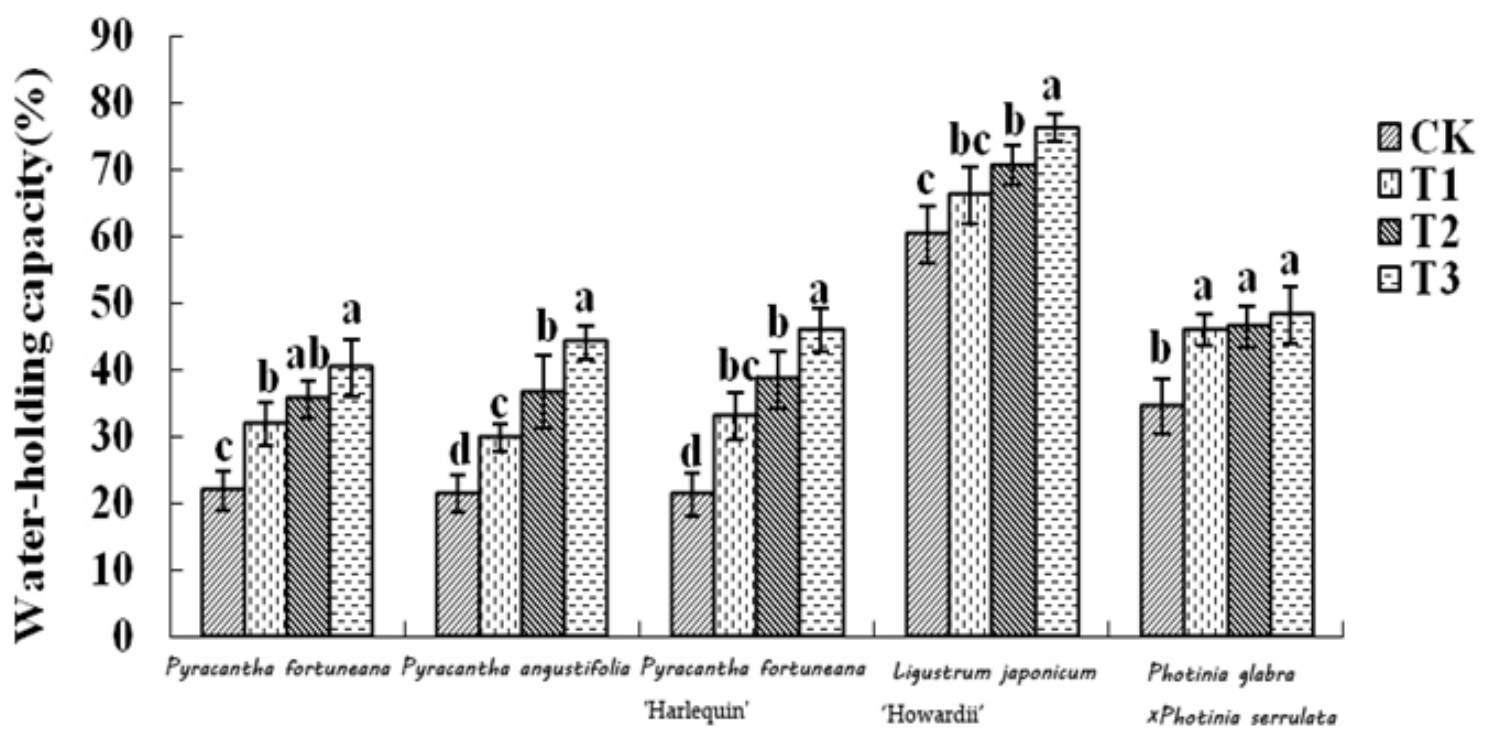

Fig.1 The effects of different water treatments on water-holding capacities of five plants

Effects of water stress on leaf relative water content (LRWC) of five shrubs. Drought stress caused the decrease of water content in soil, which was directly reflected by the decrease of LRWC. As shown in Fig. 2, all of the five plants showed lrwc decline under water stress, and the descending amplitude was almost the same. All five kinds of plants' LRWC change degree is little on T1 and T2, water loss is not very serious, its normal water metabolism isn't affected, but the 
LRWC on T3 decline amplitude increases, which indicated that the severe stress causes the plant body water deficit to affect its normal physiological function. The LRWC of the Pyracantha fortuneana, Ligustrum japonicum 'Howardii'and Photinia glabra $\times$ Photinia serrulata were about $10 \%$ higher than that of the Pyracantha angustifolia and Pyracantha fortuneana 'Harlequin', and the drought resistance was also higher.

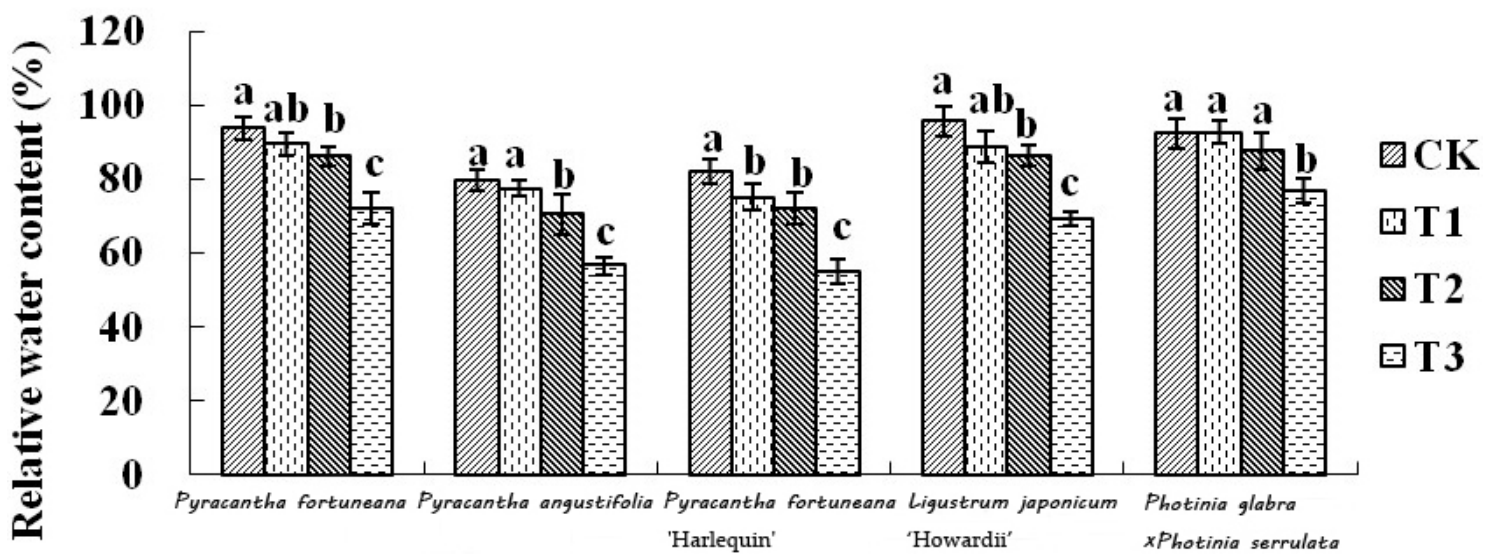

Fig.2 The effects of different water treatments on relative water cotent of five plants

Effects of water stress on morphological indices of five species of shrubs. Different water stress gradients inhibited the growth of plant height and ground diameter in different degrees. As shown in table 1, the height growth of the Pyracantha fortuneana, Pyracantha angustifolia and Photinia glabra $\times$ Photinia serrulata were not significantly different between $\mathrm{CK}$ and $\mathrm{T} 1$, while the T2 and T3 treatments were significantly lower than CK, and there was no significant difference between the treatments. The growth of the ground diameter was significantly lower than that of CK of the Pyracantha angustifolia, the growth of the ground diameter about all the treatments was lower than that of CK, which is only significantly different between T1 and CK. Both the growth of height and ground diameter of the Pyracantha fortuneana 'Harlequin' in all treatments were significantly lower than that of CK, but the difference between the treatments wasn't significant. Both the growth of height and ground diameter of Ligustrum japonicum 'Howardii' were lower than CK in T1 and T2, their difference also wasn't significant, and T3 was significantly lower than CK. This shows that drought stress has a serious inhibitory effect on the growth of the height and diameter of the Pyracantha fortuneana 'Harlequin'. The response of the Pyracantha fortuneana , Pyracantha angustifolia and Photinia glabra $\times$ Photinia serrulata is similar to that of the water deficit, while the growth of the height and the ground diameter of Ligustrum japonicum 'Howardii' can only be hindered in severe drought. Accordingly,the drought resistance of five species of shrubs should be: Ligustrum japonicum 'Howardii' > Pyracantha fortuneana> Pyracantha angustifolia> Photinia glabra $\times$ Photinia serrulata $>$ Pyracantha fortuneana 'Harlequin'.

Effects of water stress on growth of five shrubs. The lower the growth grade is, the better the growth potential is, indicating that the less the plant growth condition is affected by water stress, the higher the drought resistance is. As shown in Fig.3, Under the treatment of T1 and CK, Pyracantha fortuneana, Pyracantha angustifolia and Ligustrum japonicum 'Howardii' were consistent in growth, under the T2 their growth is weakening, but Pyracantha angustifolia is relatively less, at the T3 Ligustrum japonicum 'Howardii' is relatively better. The growth conditions of Photinia glabra $\times$ P.fraseri under the treatment of T2 and T3 were better than that of Pyracantha fortuneana 'Harlequin', the growth condition at T1 was not as good as that of Pyracantha angustifolia, At T3, Pyracantha fortuneana 'Harlequin' even stopped growing. Thus it can be seen that the drought resistance of each species is Ligustrum japonicum 'Howardii'> Pyracantha fortuneana > Pyracantha angustifolia $>$ Photinia glabra $\times$ P. fraseri $>$ Pyracantha fortuneana 'Harlequin'. 
Table 1 Effects of different water treatments on the growth indices of five plants

\begin{tabular}{|c|c|c|c|c|c|c|c|}
\hline \multirow[b]{2}{*}{ Trees } & \multirow[b]{2}{*}{ Treatments } & \multicolumn{3}{|c|}{ Height $(\mathrm{cm})$} & \multicolumn{3}{|c|}{ Diameter $(\mathrm{mm})$} \\
\hline & & $\begin{array}{c}\text { Before } \\
\text { treatment }\end{array}$ & $\begin{array}{c}\text { After } \\
\text { treatment }\end{array}$ & Increment & Before treatment & After treatment & Increment \\
\hline \multirow{4}{*}{$\begin{array}{l}\text { Pyracantha } \\
\text { fortuneana }\end{array}$} & CK & $20.83 \pm 3.81 \mathrm{a}$ & $42.67 \pm 4.10 \mathrm{a}$ & $12.07 \pm 0.47 \mathrm{a}$ & $4.57 \pm 0.55 \mathrm{a}$ & $4.67 \pm 0.55 \mathrm{a}$ & $0.10 \pm 0.01 \mathrm{a}$ \\
\hline & $\mathrm{T} 1$ & $30.50 \pm 2.57 \mathrm{a}$ & $41.17 \pm 2.46 \mathrm{a}$ & $10.67 \pm 0.12 \mathrm{ab}$ & $4.77 \pm 0.55 \mathrm{a}$ & $4.84 \pm 0.53 \mathrm{a}$ & $0.07 \pm 0.03 \mathrm{ab}$ \\
\hline & $\mathrm{T} 2$ & $30.10 \pm 2.93 a$ & $39.50 \pm 2.95 \mathrm{a}$ & $9.40 \pm 0.10 \mathrm{~b}$ & $4.67 \pm 0.25 \mathrm{a}$ & $4.73 \pm 0.26 a$ & $0.06 \pm 0.01 b$ \\
\hline & T3 & $30.17 \pm 2.62 \mathrm{a}$ & $39.70 \pm 2.90 \mathrm{a}$ & $9.53 \pm 2.50 \mathrm{~b}$ & $4.67 \pm 0.32 \mathrm{a}$ & $4.73 \pm 0.32 \mathrm{a}$ & $0.06 \pm 0.01 \mathrm{~b}$ \\
\hline \multirow{4}{*}{$\begin{array}{l}\text { Pyracantha } \\
\text { angustifolia }\end{array}$} & $\mathrm{CK}$ & $36.67 \pm 5.69 \mathrm{a}$ & $50.67 \pm 3.79 a$ & $14.00 \pm 2.00 \mathrm{a}$ & $5.30 \pm 0.40 \mathrm{a}$ & $5.36 \pm 0.40 \mathrm{a}$ & $0.06 \pm 0.01 \mathrm{a}$ \\
\hline & T1 & $36.67 \pm 3.51 \mathrm{a}$ & $48.00 \pm 1.00 \mathrm{a}$ & $11.33 \pm 2.52 \mathrm{ab}$ & $4.93 \pm 0.47 \mathrm{a}$ & $4.98 \pm 0.48 \mathrm{a}$ & $0.05 \pm 0.01 b$ \\
\hline & $\mathrm{T} 2$ & $35.67 \pm 2.08 \mathrm{a}$ & $45.67 \pm 3.06 \mathrm{a}$ & $10.00 \pm 1.00 \mathrm{~b}$ & $5.57 \pm 0.38 \mathrm{a}$ & $5.60 \pm 0.38 \mathrm{a}$ & $0.04 \pm 0.01 \mathrm{~b}$ \\
\hline & T3 & $37.33 \pm 3.79 a$ & $47.00 \pm 5.20 \mathrm{a}$ & $9.67 \pm 1.53 b$ & $5.27 \pm 0.32 \mathrm{a}$ & $5.31 \pm 0.32 a$ & $0.05 \pm 0.01 b$ \\
\hline \multirow{4}{*}{$\begin{array}{l}\text { Pyracantha } \\
\text { fortuneana } \\
\text { 'Harlequin' }\end{array}$} & $\mathrm{CK}$ & $20.33 \pm 3.00 \mathrm{a}$ & $27.00 \pm 3.61 \mathrm{a}$ & $7.00 \pm 1.00 \mathrm{a}$ & $3.15 \pm 0.20 \mathrm{a}$ & $3.26 \pm 0.22 \mathrm{a}$ & $0.11 \pm 0.02 \mathrm{a}$ \\
\hline & $\mathrm{T} 1$ & $22.33 \pm 1.53 \mathrm{a}$ & $27.00 \pm 2.00 \mathrm{a}$ & $4.67 \pm 0.58 b$ & $3.13 \pm 0.32 \mathrm{a}$ & $3.18 \pm 0.32 \mathrm{a}$ & $0.05 \pm 0.01 \mathrm{~b}$ \\
\hline & $\mathrm{T} 2$ & $23.67 \pm 2.08 \mathrm{a}$ & $28.53 \pm 2.16 \mathrm{a}$ & $4.87 \pm 0.81 \mathrm{~b}$ & $3.10 \pm 0.26 \mathrm{a}$ & $3.17 \pm 0.27 \mathrm{a}$ & $0.07 \pm 0.01 \mathrm{~b}$ \\
\hline & T3 & $20.67 \pm 2.52 \mathrm{a}$ & $25.33 \pm 3.21 \mathrm{a}$ & $4.67 \pm 1.53 b$ & $3.29 \pm 0.25 \mathrm{a}$ & $3.35 \pm 0.25 a$ & $0.06 \pm 0.01 \mathrm{~b}$ \\
\hline \multirow{4}{*}{$\begin{array}{l}\text { Ligustrum } \\
\text { japonicum } \\
\text { 'Howardii' }\end{array}$} & CK & $25.63 \pm 2.74 a$ & $34.80 \pm 1.28 \mathrm{a}$ & $9.17 \pm 1.50 \mathrm{a}$ & $4.03 \pm 0.15 a$ & $4.10 \pm 0.15 a$ & $0.08 \pm 0.01 \mathrm{a}$ \\
\hline & T1 & $25.90 \pm 2.36 \mathrm{a}$ & $34.73 \pm 1.90 \mathrm{a}$ & $8.83 \pm 0.57 \mathrm{ab}$ & $3.98 \pm 0.22 \mathrm{a}$ & $4.04 \pm 0.23 \mathrm{a}$ & $0.06 \pm 0.01 \mathrm{ab}$ \\
\hline & $\mathrm{T} 2$ & $25.90 \pm 2.36 \mathrm{a}$ & $32.93 \pm 2.62 \mathrm{a}$ & $7.63 \pm 0.21 \mathrm{ab}$ & $4.10 \pm 0.17 \mathrm{a}$ & $4.15 \pm 0.16 \mathrm{a}$ & $0.05 \pm 0.01 \mathrm{ab}$ \\
\hline & T3 & $24.93 \pm 3.49 \mathrm{a}$ & $32.13 \pm 4.50 \mathrm{a}$ & $7.20 \pm 1.21 \mathrm{~b}$ & $4.00 \pm 0.18 \mathrm{a}$ & $4.05 \pm 0.20 \mathrm{a}$ & $0.05 \pm 0.02 \mathrm{~b}$ \\
\hline \multirow{4}{*}{$\begin{array}{c}\text { Photinia } \\
\text { glabra } \\
\times \text { Photinia } \\
\text { serrulata }\end{array}$} & CK & $19.70 \pm 3.24 a$ & $22.03 \pm 3.12 \mathrm{a}$ & $4.04 \pm 1.13 \mathrm{a}$ & $4.28 \pm 0.13 a$ & $4.37 \pm 0.12 \mathrm{a}$ & $0.09 \pm 0.03 \mathrm{a}$ \\
\hline & T1 & $20.67 \pm 2.17 \mathrm{a}$ & $23.64 \pm 3.08 \mathrm{a}$ & $2.97 \pm 0.91 \mathrm{ab}$ & $4.31 \pm 0.29 \mathrm{a}$ & $4.37 \pm 0.25 \mathrm{a}$ & $0.06 \pm 0.04 \mathrm{ab}$ \\
\hline & $\mathrm{T} 2$ & $20.53 \pm 2.29 a$ & $22.94 \pm 2.11 \mathrm{a}$ & $2.41 \pm 0.21 \mathrm{~b}$ & $4.15 \pm 0.19 a$ & $4.19 \pm 0.21 \mathrm{a}$ & $0.04 \pm 0.02 b$ \\
\hline & $\mathrm{T} 3$ & $20.17 \pm 2.80 \mathrm{a}$ & $24.21 \pm 2.54 \mathrm{a}$ & $2.33 \pm 0.27 b$ & $4.22 \pm 0.04 a$ & $4.29 \pm 0.04 a$ & $0.07 \pm 0.01 \mathrm{ab}$ \\
\hline
\end{tabular}

Note: Different letters indicate significant difference at 5\% level among different treatments.

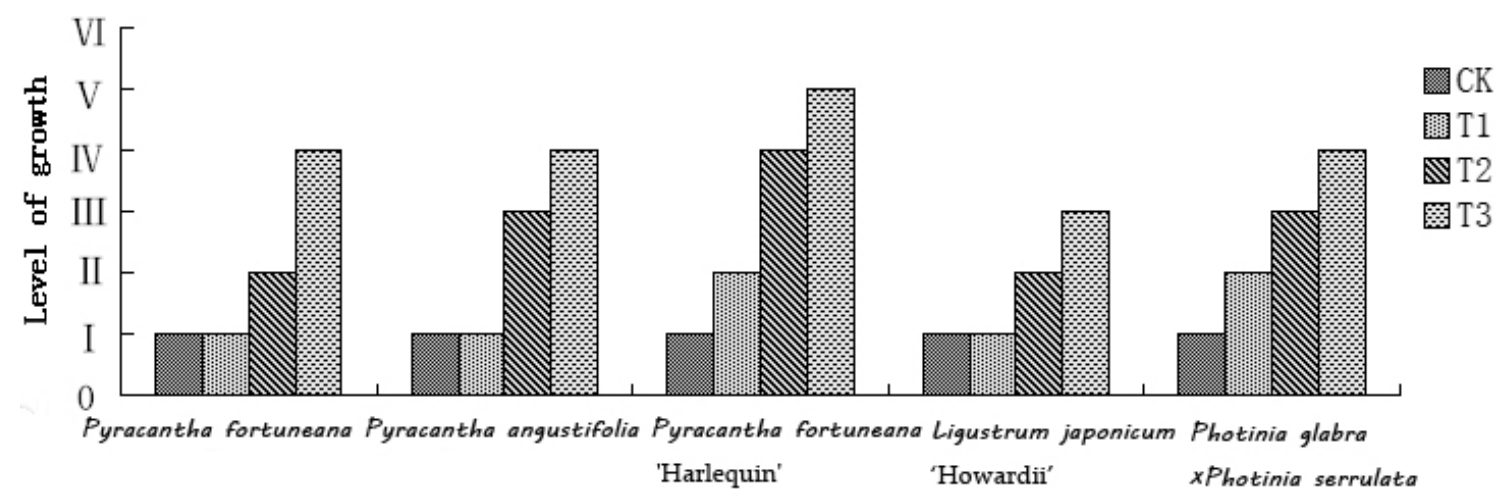

Fig.3 The condition of different water treatment on five kinds of plant growth

\section{Conclusions}

It is found that under drought stress, the water retention of five shrubs is obviously enhanced, thus effectively preventing the excessive consumption of moisture in the ground leaf part to adapt to the survival under the conditions of arid environment. The results showed that the drought resistant ability of five species of shrubs from strong to weak as follows: Ligustrum japonicum 'Howardii', Pyracantha fortuneana, Pyracantha angustifolia, Photinia glabra $\times$ Photinia serrulata, Pyracantha fortuneana 'Harlequin'. It was found with several comprehensive indicators that the drought tolerance of Ligustrum japonicum 'Howardii' was significantly higher than that of the other four species, and its adaptability to water deficit was stronger, Therefore, according to the drought resistance ability of tree species, it is suggested that planting Ligustrum japonicum 'Howardii' and Pyracantha fortuneana, in areas with severe water shortage can effectively maintain soil and water and improve the ecological environment.

\section{References}

[1] J.J.Zhang, H.M.Li and J.J.Xu: Acta Ecologica Sinica Vol.31(2011),p.7056.

[2] G.Y.Yang, L.Wang and H.Wang: Journal of Agricultural Engineering Vol. 26(2010), p.2. 
[3] L.Ibrahim and M.F.Pore. Tree Physiology Vol. 18(1998), p.482.

[4] W.G.Li, X.Li and M.T.Hou: Chinese Journal of Ecological Agriculture Vol.20 (2012), p.645.

[5] H.B.Shao, L.Y.Chu and C.A.Jaleel : Comptes Rendus Biologies Vol. 331(2008), p. 215

[6] S.M.Cui, L.Cheng and N.Ni: Journal of the Japanese Society for Horticultural Science Vol.72(2003), p359.

[7] L.Li, Z.Q.Jia and Y.J.Zhu: Desert of China Vol. 30(2010), p.1053.

[8] Plant Physiology Teaching and Research Group, Department of Biology, East China Normal University: Determination of Plant Tissue Moisture Content (Advanced Education Press, Beijing,China 1980)

[9] Y.M.Huang, J.Zhang and C.D.Luo: Sichuan Forestry Technology Vol.4(1998),p. 31

[10]T.Wu. Drought Resistance and Application of Garden Cover Plants (Master Thesis, Nanjing Forestry University, China 2002). 